\title{
Plankton tethering to assess spatial patterns of predation risk over a coral reef and seagrass bed
}

\author{
Stephan G. Bullard ${ }^{1}$, Mark E. Hay ${ }^{2, *}$ \\ ${ }^{1}$ Institute of Marine Sciences, University of North Carolina at Chapel Hill, 3431 Arendell St., Morehead City, \\ North Carolina 28557, USA \\ ${ }^{2}$ School of Biology, Georgia Institute of Technology, Atlanta, Georgia 30332-0230, USA
}

\begin{abstract}
Difficulties associated with manipulating plankton in situ have limited the ability of investigators to assess among-habitat variation in predation risk for plankton. We used plankton tethering units (PTUs) to tether zooplankton in a variety of reef and seagrass habitats, and used field and laboratory assays to test PTUs for tethering artifacts. Tethering did not affect the survivorship of 5 species of plankton (sizes $<1$ to $6 \mathrm{~mm}$ ), indicating that the method works with a range of planktonic organisms. We then used the reef mysid Mysidium columbiae in additional assays and found that: (1) mysids remained on PTUs unless they were attacked by predators; (2) PTUs did not prevent planktivorous fishes from consuming tethered mysids; (3) untethered mysids commonly evaded predators, while mysids on PTUs did not; (4) the same types of predators consumed untethered and tethered mysids in the field; and (5) fishes were neither attracted to nor repelled from PTUs. We used PTUs and mysids to assess predation risk for plankton over various coral reef or seagrass habitats. Risk of attack varied among habitats and was correlated with abundance of planktivorous fishes. On the reef, attack rates were most intense over a topographically complex reef ledge, less intense over the less structurally complex center of the reef, and least intense over a structurally simple sand plain. Within the seagrass bed, attack rates were highest at the edge of the bed and less intense to the center of the seagrass bed and over an adjacent sand plain. Thus, attack rates at these sites varied tremendously over small spatial scales (meters).
\end{abstract}

KEY WORDS: Invertebrate larvae · Mysids · Mysidium columbiae · Planktivory • Tethering • Zooplankton

\section{INTRODUCTION}

Planktivory by fishes can be intense (Hiatt \& Strasburg 1960, Glynn 1973, Hobson \& Chess 1978, Roughgarden et al. 1988, Hobson 1991) and can affect zooplankton and larval abundance as water masses pass over reefs or through kelp beds (Glynn 1973, Bray 1981, Gaines \& Roughgarden 1987, Olson \& McPherson 1987, Stoner 1990). Additionally, numerous reef and seagrass zooplankters possess traits such as demersalism (Emery 1968, Lewis \& Boers 1991, Madhupratap et al. 1991, Walters 1991, Walters \& Bell 1994), schooling behaviors (Hamner \& Carleton 1979,

*Corresponding author. E-mail: mark.hay@biology.gatech.edu
O'Brien \& Ritz 1988), and chemical defenses (Lindquist et al. 1992, 1997, Lindquist \& Hay 1996) that reduce their susceptibilities to planktivorous fishes. The widespread incidence of defenses and escape behaviors among resident reef and seagrass zooplankters suggests that planktivory may act as a significant selective force in these habitats.

Despite the apparent importance of predation, the relative levels of planktivory among tropical habitats has rarely been assessed (but see Olson \& McPherson 1987, Davis \& Butler 1989, Stoner 1990, Acosta \& Butler 1999). For nonplanktonic organisms, tethering experiments, in which organisms are attached to a restraining device (tether) and placed in the field, have been a powerful tool for evaluating among-habitat differences in attack 
rates or potential predation pressure (Aronson \& Heck 1995, and references within). Although investigators have tethered some plankton (Paffenhöffer \& Lewis 1989, Thetmeyer \& Kils 1995, Acosta \& Butler 1999), this approach has been uncommon due to the difficulties of manipulating tethered plankton in the field (but see Acosta \& Butler 1999). Tethering small plankton (i.e. most plankton) has been especially difficult and rare.

To work with tethered plankton, logistical problems associated with transporting tethered plankton to the field must be overcome. Tethered plankton must stay continuously submerged during transport, the tethers cannot become entangled, and the tethered plankton must be able to be deployed quickly without damage in the field. Additionally, tethering can produce biases that confound results (e.g. Peterson \& Black 1994). For example, tethering can make organisms more or less susceptible to predators by affecting their behavior, apparency, or mortality. In addition, complex interactions can occur between tethers and treatments if tethers differentially affect the susceptibility of tethered organisms in different habitats (Peterson \& Black 1994). Such interactions will often depend on specific aspects of prey behavior or apparency, and the way these traits vary as a function of the local habitat. Because these complex interactions will often be species specific, the spatial patterns of attack or mortality for one type of prey organism may not be predictive for prey with different behaviors. In addition to complexities associated with tethering by habitat interactions, tethering methods also need to be evaluated for less complex artifacts arising from direct effects of tethers.

We describe and test the plankton tethering unit (PTU), a modification of existing tethering techniques that allows for the deployment and recovery of individual plankton among discrete habitats in the field. After examining PTUs for artifacts, we used PTUs to assess the spatial variance in predation risk among habitats over a coral reef and seagrass bed. Although we tethered reef mysids Mysidium columbiae, our goal was to assess the relative risk of attack for a generalized plankter as a function of habitat. Thus, we used mysids as a general planktonic 'bait.' It was not our intention to determine how mysids in particular dealt with predation. We believe that it will be possible to use PTUs to directly assess planktivory for individual plankton species; however, in order to do so, treatment-specific biases may need to be examined for each species investigated.

\section{MATERIALS AND METHODS}

Study sites and organisms. Investigations were conducted at 2 locations near Key Largo, Florida, USA.
The first location $\left(24^{\circ} 59.643^{\prime} \mathrm{N}, 80^{\circ} 24.407^{\prime} \mathrm{W}\right)$ was composed of numerous patch reefs separated by unconsolidated rubble and sand. We selected 1 of the patch reefs and worked within 3 distinct habitats on, or near, the reef-a topographically complex ledge on the seaward edge of the reef, the more structurally simple center of the reef (hereafter referred to as reef center), and a sand plain shoreward of the reef. The ledge rose from a rubble-strewn sand plain in an abrupt change of depth from ca 6.5 to $5.0 \mathrm{~m}$. The ledge was nearly linear, ca $2 \mathrm{~m}$ wide, and had numerous fissures and crevices. Landward of the ledge was the reef center. Unlike the ledge, the reef center was structurally simple, about $25 \mathrm{~m}$ wide, and ranged in depth from ca 4.0 to $5.0 \mathrm{~m}$. Landward from the reef center was a sand plain at ca $6.5 \mathrm{~m}$ depth. Underwater visibility at this site was variable and ranged from less than 1 to $20 \mathrm{~m}$, with visibilities of greater than $12 \mathrm{~m}$ being common.

The second location was a seagrass bed $\left(25^{\circ} 00.663^{\prime} \mathrm{N}\right.$, $80^{\circ} 24.671^{\prime} \mathrm{W}$ ) that we also characterized into 3 habitats - the edge of the bed, the interior of the bed, and the sand plain beyond the bed. The seagrass bed ran North-South at a depth of ca $6.0 \mathrm{~m}$. There was a distinct edge at the northern margin of the bed composed of exposed rhizomes and plant debris. This edge was about $0.75 \mathrm{~m}$ across and exhibited an abrupt change of depth from ca 6.4 to $6.0 \mathrm{~m}$. North of the edge was a sand plain at ca $6.4 \mathrm{~m}$ depth. Underwater visibility at this site was generally lower than the reef site and ranged from less than 1 to $10 \mathrm{~m}$, averaging ca $6 \mathrm{~m}$.

In initial assays evaluating the utility of the tethering technique, we tethered 5 different species of zooplankton-the copepod Centropages typicus, larvae of the crabs Dyspanopeus sayi, Libinia dubia, and Pinnixa chaetopterana, and the mysid Mysidium columbiae. The mysids (6.29 $\pm 0.16 \mathrm{~mm}$ total length) were chosen for use in more extensive laboratory and field assays because they were common in the Florida Keys, were easy to collect in large numbers, and occurred in a variety of habitats (Brattegard 1969), form large aggregations that persist in single locations over time (Clutter 1969, Hahn \& Itzkowitz 1986), and were predictably available at our reef site. To collect mysids, SCUBA divers swept them into 3.81 plastic bags as the mysids bunched together in response to the diver. Mysids were maintained at the laboratory in $15 \mathrm{l}$ of aerated seawater until used in assays (no longer than $48 \mathrm{~h}$ after capture).

In laboratory assays, we used the bluehead wrasse Thalassoma bifasciatum as our assay predator. Bluehead wrasses were one of the most abundant fishes at our reef sites and are voracious planktivores (Hairston et al. 1982). Wrasses (6.15 $\pm 1.15 \mathrm{~cm}$ standard length) were netted by divers, returned to the lab, and held individually in 3.51 plastic bowls receiving recirculat- 
ing seawater. Wrasses were fed twice daily on a mixed diet of live brine shrimp Artemia sp., frozen brine shrimp, and frozen blood worms.

The plankton tethering unit. Field assays were conducted using plankton tethering units (PTUs, see Fig. 1A) comprised of 3 basic components, a transparent acrylic rod $(40 \mathrm{~cm}$ long $\times 0.5 \mathrm{~cm}$ diameter), transparent aquarium tubing $(0.5 \mathrm{~cm}$ long $\times 0.5 \mathrm{~cm}$ diameter), and transparent nylon monofilament line $(30 \mathrm{~cm}$ long $\times 100 \mu \mathrm{m}$ diameter). Two pieces of tubing were placed $1 \mathrm{~cm}$ apart within $5 \mathrm{~cm}$ of the top of the rod and held the monofilament line in place. A third piece of tubing was placed $10 \mathrm{~cm}$ from the base of the rod and marked the depth to which the PTU was to be inserted into the substratum in the field. The monofilament line was tied between the 2 pieces of tubing near the top of the rod.

Planktonic organisms were attached to the PTUs by touching cyanoacrylate-coated monofilament line to the organism's carapace. The free end of the monofilament line attached to a PTU was dipped into a small pool of cyanoacrylate, and an individual organism was then pipetted out of a holding container and onto a moist $102 \mu \mathrm{m}$ mesh sieve. Once the organism was on the sieve, a finger was wiped across the bottom of the sieve to draw off excess water and to partially dry the outer portion of the organism. Under 25 to $40 \times$ magnification, the end of the monofilament line with the wet cyanoacrylate was lightly touched to the organism's carapace. In many cases the glue adhered to the organism instantly. If a bond did not develop, a drop of seawater was pipetted onto the organism; this instantly formed the bond. To minimize potential damage to the organism, the monofilament was positioned so that the cyanoacrylate was kept well away from the organism's eyes and legs.

Once an organism was attached to the monofilament, the PTU was prepared for transport to the field. The tethered organism was placed inside a seawater-filled $20 \mathrm{ml}$ scintillation vial and the monofilament line was fed into the vial with forceps. It was important to ensure that the scintillation vials were completely filled with seawater before the organism was added, otherwise small bubbles formed on the submerged monofilament and made it positively buoyant. Once the organism and monofilament line were inside the vial, the scintillation vial cap was gently screwed onto the vial. A rubber band secured the vial to the rod. Finally, a $2 \times 8 \mathrm{~cm}$ piece of parafilm was wrapped around the vial and the acrylic rod to form a watertight seal and to help hold the vial to the acrylic rod (Fig. 1B).

Once prepared for transport, PTUs were placed in mesh bags and transported to the field in a water-filled cooler to minimize temperature changes and breakage during transport. At the field site, PTUs were deployed by SCUBA divers or snorkelers. In soft sediments, PTUs were deployed by inserting each rod into the substratum up to the level of the lower piece of aquarium tubing $(10 \mathrm{~cm})$. Once a PTU had been positioned, the rubber band and parafilm were removed, the scintillation cap was carefully unscrewed, and the tethered organism was released by slowly pulling the vial down current.

Because PTUs could not be inserted into hard substrata (reefs), PTUs were slightly modified for reef deployments. Before tethering began, the lower $10 \mathrm{~cm}$ of the acrylic rod was removed. At the field site, a $9 \mathrm{~cm}$ galvanized nail with one half of the head removed was driven $2 \mathrm{~cm}$ into the substratum. A PTU was laid flush against the nail and attached using a $21.0 \times 0.4 \mathrm{~cm}$ cable tie. Once the PTU was in place, the tethered organism was released as described above. For assays involving comparisons among soft and hard substrata habitats, controls consisting of a nail with cable tie attached were deployed next to the soft substrata PTUs.

Assessment of potential artifacts. Tethering can affect the behavior or survivorship of tethered organisms. To determine if zooplankton survived the tethering procedure, we examined the survivorship of tethered versus untethered individuals for 5 species of

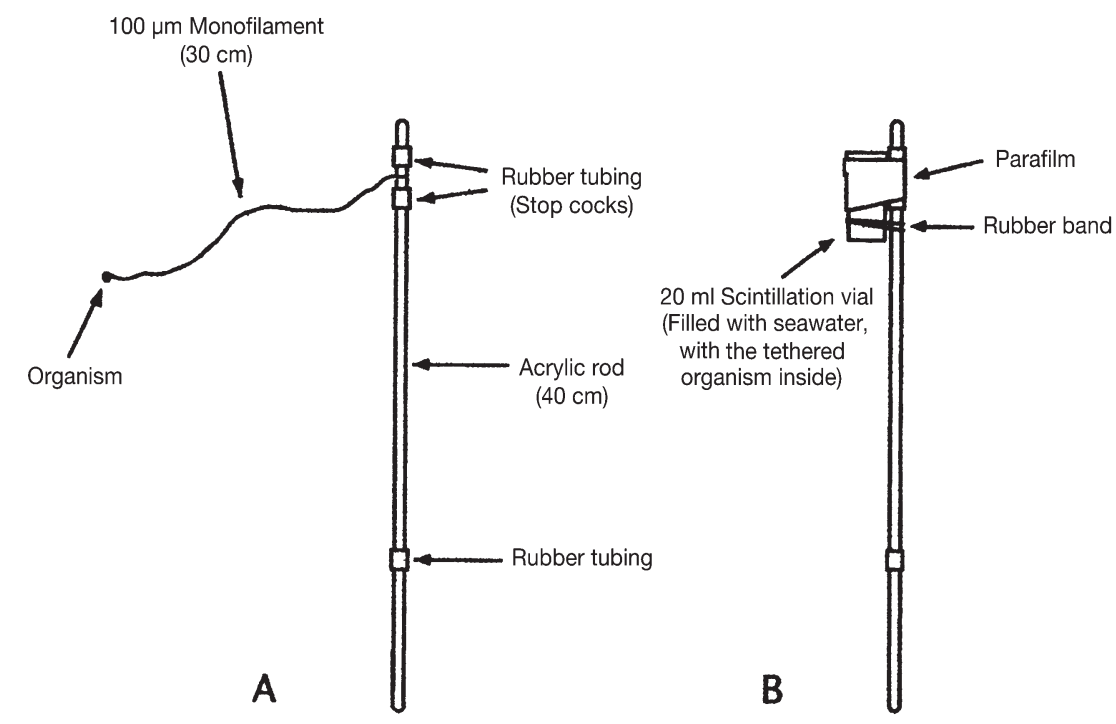

Fig. 1. The planktonic tethering unit (PTU). (A) PTU as seen deployed; (B) PTU prepared for transport to the field 
plankton (the copepod Centropages typicus, larvae of the crabs Dyspanopeus sayi, Libinia dubia, and Pinnixa chaetopterana, and the mysid Mysidium columbiae). Assays were performed by placing individual tethered and untethered plankton into separate seawater-filled $20 \mathrm{ml}$ scintillation vials in order to mimic the conditions experienced by plankton as they were transported to field sites on PTUs. Survivorship was assessed after $6 \mathrm{~h}$, when each individual was classified as alive (moving), dead (not moving), or detached from its tether. Differences in the survivorship of tethered versus untethered larvae were evaluated using Fisher's Exact test.

A laboratory assay was performed to determine whether wrasses would consume tethered mysids. Individual wrasses were offered an untethered mysid followed by a tethered mysid. Fish could either consume or reject (spit out) the offered organisms. Differences between consumption of tethered versus untethered mysids were evaluated using Fisher's Exact test. To further assess the possibility that the monofilament line made Mysidium columbiae unpalatable to fishes, direct field observations were made of encounters between tethered mysids and fishes during the course of field assays.

To determine whether mysids with cyanoacrylate on their carapace were more apparent to fishes than mysids without cyanoacrylate, we simultaneously offered mysids with and without cyanoacrylate to wrasses in the laboratory. 'Glued' mysids were prepared by placing a small drop of cyanoacrylate equal to the amount used to attach organisms to PTUs onto their carapace. 'Nonglued' mysids did not have cyanoacrylate on their carapaces. Two pipettes, one containing a glued mysid, the other containing a nonglued mysid, were placed $2 \mathrm{~cm}$ in front of a wrasse and both mysids were squirted into the bowl simultaneously. We recorded which mysid the fish attacked first. Differences in the attack rate on glued versus nonglued mysids were evaluated using chi-squared analysis. We also obtained data for pinfish Lagodon rhomboides feeding on glued versus nonglued copepods Centropages typicus. Assays with pinfish were conducted in the same fashion as described for mysids.

To determine whether live, untethered Mysidium columbiae could avoid predators, we followed individual live and dead mysids released in the reef center habitat. Individual mysids were captured from a large aggregation and moved to a release point ca $10 \mathrm{~m}$ cross current from their home aggregation. The release point was an area of similar habitat to the mysid's home aggregation, but without mysids. Mysids were released into the water column either alive or dead ( $\mathrm{n}=14$ for each). Dead mysids were produced by squeezing the mysids in a plastic bag with enough force to kill them, but not to rupture their carapace or abdomen. Once released, each mysid was followed at a distance of 1 to $1.5 \mathrm{~m}$ until it was consumed by a predator, rejoined a mysid aggregation, or was lost from view. To ensure consistency among observations, all mysids were followed by a single investigator (SGB). Because mysids were initially released in an area without other mysids, individual unmarked mysids could be followed without having to worry about distinguishing them from other mysids. Differences in the number of live versus dead mysids consumed by predators during $1 \mathrm{~min}$ were examined using Chi-squared analysis.

The results from the above assay demonstrated that live, untethered mysids were better able to evade predators than dead mysids. To determine whether live Mysidium columbiae could behaviorally evade predators while on PTUs, we deployed PTUs with live and dead mysids (killed by heat shock) and recorded the time it took fish to locate and consume these mysids in the field. Sites for deployment were selected at random on the reef center. Once a PTU had been deployed, investigators moved $2 \mathrm{~m}$ away and recorded the time it took for fishes to consume the tethered mysid. Logistically, it was impossible for us to complete this assay in a single day. Instead, we collected data over 2 d. A 2-way ANOVA compared treatments, with mortality (live versus dead) and day as factors. Because data were normal (Shapiro-Wilk $W$-tests) but had unequal variances (Bartlett tests), data were log transformed before analysis.

We conducted field assays to determine whether the types of predators that fed on untethered mysids were the same as those that fed on mysids tethered to PTUs. We had previously shown that untethered live Mysidium columbiae were better able to evade predators than dead mysids. Thus, to ensure that behavior did not confound our results, we used dead mysids (killed by heat shock) for these assays. Because results could vary among habitats, we conducted assays on both the ledge and reef center habitats. Deployment sites within habitats were selected randomly. Once a site was established, either an untethered mysid or a mysid on a PTU was deployed. For untethered mysids, investigators released the mysid about $0.3 \mathrm{~m}$ above the reef, then followed the mysid at a distance of 1 to $1.5 \mathrm{~m}$ until it was consumed by a predator. If the untethered heatkilled mysid sank to the bottom or, in the case of the ledge area, moved out of the habitat, the mysid was recaptured and re-deployed. For PTUs, the investigator deployed the PTU, moved $1.5 \mathrm{~m}$ away, and recorded the type of predator that consumed the mysid. If the mysid was not consumed within 5 min, a new site was selected and the PTU was re-deployed. Both tethered and untethered mysids were generally attacked 
by predators during the first deployment; however, about $20 \%$ needed to be re-deployed. Fisher's Exact tests were used to assess differences between the consumption of untethered versus tethered mysids for each species of fish in both habitats.

To determine whether PTU placement affected fish behavior, we recorded the number of fishes that visited sites with and without PTUs on the reef center. At randomly selected locations, either an empty quadrat $(0.4 \times 0.4 \mathrm{~m})$ or a quadrat with a PTU in the center was deployed. Quadrats were defined by laying $9 \mathrm{~cm}$ long nails on the substratum at each of the 4 corners of the quadrat. Quadrats without PTUs consisted of only the nails and were not otherwise disturbed. Quadrats with PTUs were marked with nails and an un-baited PTU was deployed in the center. After preparing a quadrat with or without a PTU, the investigator moved ca $2 \mathrm{~m}$ away and recorded the number and types of fishes that passed through the plane of the quadrat for the time intervals 0 to $1 \mathrm{~min}$ and 5 to $6 \mathrm{~min}$ after deployment. Differences between the number of fishes visiting sites with and without PTUs for each time interval and between time intervals were examined using MannWhitney $U$-tests.

Predation risk assays. To assess the relative levels of predation risk among our 3 reef habitats, 10 PTUs with live Mysidium columbiae were deployed on the ledge, 10 on the reef center ( $5 \mathrm{~m}$ behind the ledge), and 10 on the sand plain ( $3 \mathrm{~m}$ behind the shoreward edge of the reef). In each habitat, PTUs were deployed in a linear transect with ca $1.5 \mathrm{~m}$ between each PTU. Although the ledge was more structurally complex than the other 2 habitats, PTUs on the ledge projected above the surrounding relief and no PTUs were shielded by substrata in any habitat. Once deployed, PTUs were allowed to stand for $10 \mathrm{~min}$. At the end of this time, an investigator swam the line of PTUs and recorded the presence or absence of mysids. Thus, the percentage of mysids present and absent from PTUs was recorded for each habitat on each day. We selected a 10 min interval for our assays because preliminary experiments suggested that roughly $50 \%$ of mysids would be consumed from the reef center in this time period. We assumed that this would allow detection of higher or lower rates of attack in other habitats relative to the reef center. This assay was replicated on 5 separate days, for a total of 50 mysids deployed in each habitat. An ANOVA was performed on the percentage of mysids missing from each habitat using days as replicates $(\mathrm{n}=5)$.

Fish counts were performed on the ledge, reef center, and sand plain by counting all of the fishes present along the $15 \mathrm{~m}$ transect defined by the PTUs used in the predation risk measurements. An investigator swam the line of PTUs with a $1 \mathrm{~m}$ wide PVC wand and recorded the numbers and types of fishes along the transect. The sample size for our fish counts was 6 instead of 5 because a fish count was also conducted during a day when we performed a preliminary assay. For the sand plain, where fish abundances were very low, it was possible to record all numbers and types of fishes on a single pass. For the reef center and the ledge, multiple passes were generally required to count all of the fishes present. If multiple passes were required, only one or a few species (determined before counting began) were counted during each pass. In general, it took 1 to 2 passes to complete a fish count on the reef center, and 3 to 5 passes to complete a fish count on the ledge. Because the data were normal (Shapiro-Wilk $W$-tests) but had unequal variances (Bartlett tests), data were log transformed and an ANOVA was used to determine whether there were differences in total fish density and planktivorous fish density among habitats. Differences among habitats were assessed using Tukey-Kramer post-hoc analyses.

We measured the topographic complexity (rugosity) of our 3 reef habitats by recording the difference in length between a beaded chain (1.2 m long, 4 beads $\mathrm{cm}^{-1}$ ) laid flush against the substratum and a similar chain stretched taut above the substratum. Measurements were taken in linear transects on the ledge ( $\mathrm{n}=$ $10)$, on the reef center $(\mathrm{n}=15)$, and on the sand plain ( $\mathrm{n}=15)$, with $1 \mathrm{~m}$ between each replicate in each habitat. The locations of the rugosity transects coincided with the locations of predation risk measurements. Differences in rugosity between habitats were examined using a Kruskal-Wallis test.

To determine the relative levels of predation risk among the three habitats at our seagrass site, 10 PTUs with live Mysidium columbiae were deployed on the edge of the bed, 10 inside the bed ( $3 \mathrm{~m}$ away from the edge), and 10 on the sand plain ( $3 \mathrm{~m}$ away from the edge of the bed). We replicated this assay on 6 separate days, for a total of 60 mysids deployed in each habitat. An ANOVA was performed on the percentage of mysids missing from each habitat using days as replicates $(\mathrm{n}=6)$.

Fish counts were conducted at the seagrass site in the same manner as described for the reef habitats. For the seagrass habitats, investigators only needed to swim transects once to count all fishes present. Because the data were normal (Shapiro-Wilk $W$-tests) but had unequal variances (Bartlett test), data were log transformed and an ANOVA was used to determine whether there were differences in total fish density and planktivorous fish density among habitats. Differences among habitats were assessed using TukeyKramer post-hoc analyses.

All observations made during our field assays were conducted by SCUBA divers, and the presence of 
Table 1. Survivorship of tethered verses untethered plankton. Tethered or untethered plankters were placed into $20 \mathrm{ml}$ scintillation vials and were allowed to stand for $6 \mathrm{~h}$. At the end of this time survivorship was assessed. During assays, 1 Centropages typicus and 2 Mysidium columbiae escaped from their tethers; these individuals were not included in survivorship assessment. Size is total length

\begin{tabular}{|lccrrr|}
\hline Species & Organism type & Size $(\mathrm{mm} \pm 1 \mathrm{SE})$ & \multicolumn{2}{c|}{$\%$ Surviving } & Th-value \\
& & & Untethered (n) & Tethered (n) \\
\hline Centropages typicus & Copepod & $1.63 \pm 0.11$ & $100 \%(19)$ & $95 \%(19)$ & 0.999 \\
Dyspanopeus sayi & Crab Zoea I & $1.24 \pm 0.11$ & $94 \%(17)$ & $94 \%(17)$ & 0.999 \\
Libinia dubia & Crab Zoea I & $1.34 \pm 0.29$ & $95 \%(19)$ & $100 \%(19)$ & 0.999 \\
Pinnixa chaetopterana & Crab Megalopa & $0.95 \pm 0.09$ & $100 \%(10)$ & $100 \%(10)$ & 0.999 \\
Mysidium columbiae & Mysid & $6.29 \pm 0.16$ & $85 \%(20)$ & $61 \%(18)$ & 0.144 \\
\hline
\end{tabular}

divers could have affected the behavior of some species of fishes (Sale 1997). If some fishes moved away from divers, they could have been underrepresented in our fish censuses and less able to consume mysids in our predation risk assays. However, visibility at our sites was often very good and it did not appear that planktivorous fishes (Pomacentrids and Labrids) were either clustered near, or avoiding, divers during the $>400 \mathrm{~h}$ we spent diving at these sites. Thus, the ecologically relevant species appeared to be present and seemed to be behaving normally during our field assays.

\section{RESULTS}

Tethering did not significantly affect the survivorship of any of the 5 species of plankton we examined (Table 1). Mortality was low for most species, and organisms rarely detached from tethers (1 Centropages typicus and 2 Mysidium columbiae detached during assays; these were excluded from evaluation of survivorship patterns). M. columbiae, however, had relatively high mortality (39\% of tethered and $15 \%$ of untethered individuals), and there was a trend ( $\mathrm{p}=$ 0.144 ) for lower survivorship of tethered mysids.

The monofilament line did not make mysids unpalatable to wrasses; $100 \%$ of both untethered and tethered
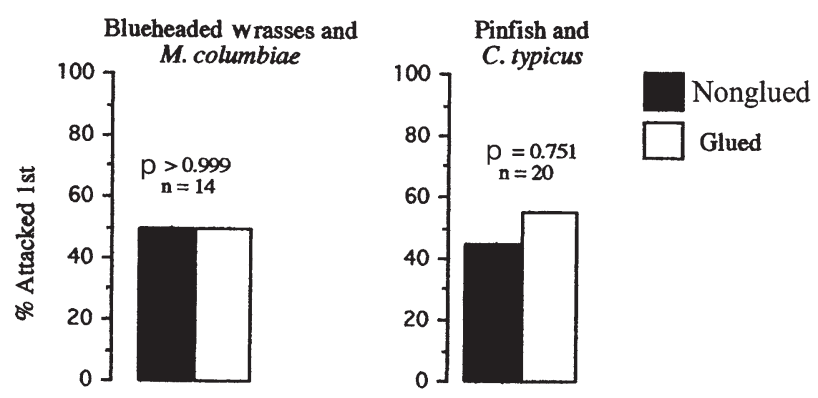

Fig. 2. Attacks on nonglued (untethered) versus glued (tethered) plankton by fishes in the laboratory. p-values are by Fisher's exact tests
Mysidium columbiae ( $\mathrm{n}=14$ each) were consumed by wrasses. Although it was not directly measured, the handling time of untethered versus tethered mysids seemed to be similar, with fish generally attacking and consuming both untethered and tethered mysids in less than $5 \mathrm{~s}$. Both wrasses and pinfish attacked glued and nonglued mysids and copepods (respectively) in equal proportions (Fig. 2), suggesting that cyanoacrylate does not affect plankton apparency or palatability to fishes.

In 75 out of 75 direct observations of field encounters, fishes ( $T$. bifasciatum, Halichoeres bivittatus, H. maculipinna, H. garnoti, and Stegastes partitus) attacked and removed mysids from PTUs on the first pass. Fishes were never seen to mouth mysids and spit them out. Additionally, mysids did not spontaneously detach from PTUs. Only 1 mysid was observed to detach from a PTU in the field without being attacked by a fish (=1.3\% of the total observations), and this was under extreme conditions of $2 \mathrm{~m}$ waves at a depth of $5 \mathrm{~m}$.

When released above a reef, $14 \%$ of live mysids were consumed by predators within the first minute of release compared to $64 \%$ of dead mysids ( $n=14$ each, $\mathrm{p}=0.010$, Fisher's exact test). Investigators were able to follow live mysids for an average of $146.0 \pm$ 24.2 (SE) $\mathrm{s}$ and dead mysids for an average $65.3 \pm$

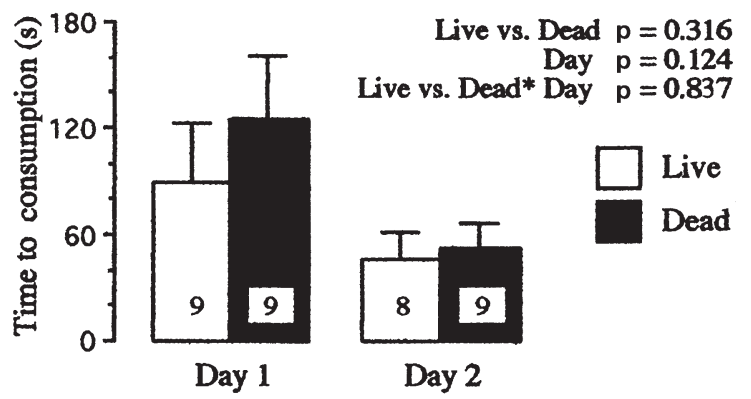

Fig. 3. Time to consumption $( \pm 1 \mathrm{SE})$ for live versus dead Mysidium columbiae attached to PTUs deployed on the reef center habitat 


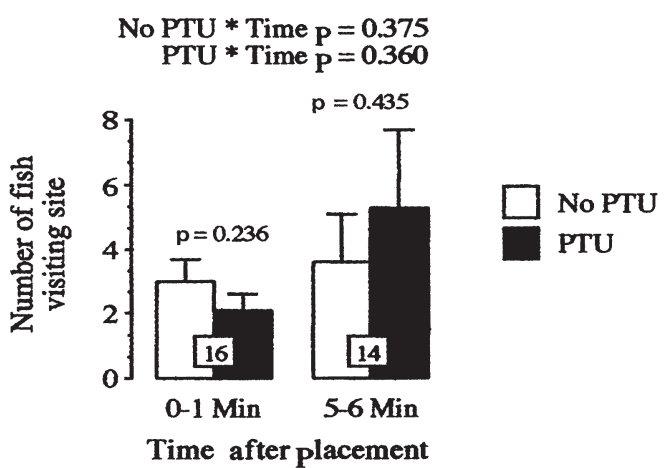

Fig. 4. Number of fishes visiting sites $( \pm 1 \mathrm{SE})$ with and without PTUs on the reef center habitat of the reef site

17.2 (SE) s. At the end of following, $14 \%$ of the live mysids had been consumed, $29 \%$ had rejoined mysid aggregations, and $57 \%$ were lost from sight as they swam towards the surface. In contrast, at the end of following for dead mysids, $86 \%$ had been consumed and $14 \%$ had settled to the bottom. Thus, live $M y$ sidium columbiae commonly avoided capture by planktivores in situations where dead mysids were consumed.

There was no significant difference in the time it took fishes to consume live versus dead mysids on PTUs, nor was there a significant difference in the time it took fishes to consume mysids between days (Fig. 3). Thus, although untethered Mysidium columbiae commonly evaded predators, $M$. columbiae on PTUs did not.

During assays in which the fates of untethered and tethered mysids were observed, planktivorous fishes consumed all of the heat killed mysids deployed in both the reef center and ledge habitats (Table 2). The same types of fishes fed on both untethered and tethered mysids, and there were no differences in the pro-

Table 2. Predators feeding on untethered and tethered Mysidium columbiae. Untethered mysids were released in the water column. Tethered mysids were attached to PTUs

\begin{tabular}{|lccc|}
\hline Reef center & $\begin{array}{c}\text { Untethered } \\
(\mathrm{n}=24) \\
\% \text { Consumed }\end{array}$ & $\begin{array}{c}\text { Tethered } \\
(\mathrm{n}=22)\end{array}$ & $\mathrm{p}$-value \\
\hline Bluehead wrasse & 71 & 73 & 0.999 \\
Yellowhead wrasse & 13 & 14 & 0.999 \\
Bicolor damselfish & 8 & 4 & 0.999 \\
Clown wrasse & 4 & 9 & 0.600 \\
Slippery Dick wrasse & 4 & 0 & 0.999 \\
Ledge & $(\mathrm{n}=17)$ & $(\mathrm{n}=18)$ & $\mathrm{p}$-value \\
\hline Bluehead wrasse & 76 & 67 & 0.711 \\
Bicolor damselfish & 18 & 28 & 0.691 \\
Yellowhead wrasse & 6 & 5 & 0.999 \\
\hline
\end{tabular}

portions of untethered versus tethered mysids consumed by any fish species in either habitat.

Deploying PTUs neither attracted nor repelled fishes (Fig. 4). No significant differences were found in the number of fishes visiting sites with or without PTUs for either time period. Additionally, there was no effect of time on treatments with PTUs or without PTUs.

All reef habitats differed significantly from each other in predation risk, number of total fishes, number of planktivorous fishes, and rugosity (Fig. 5). Habitats
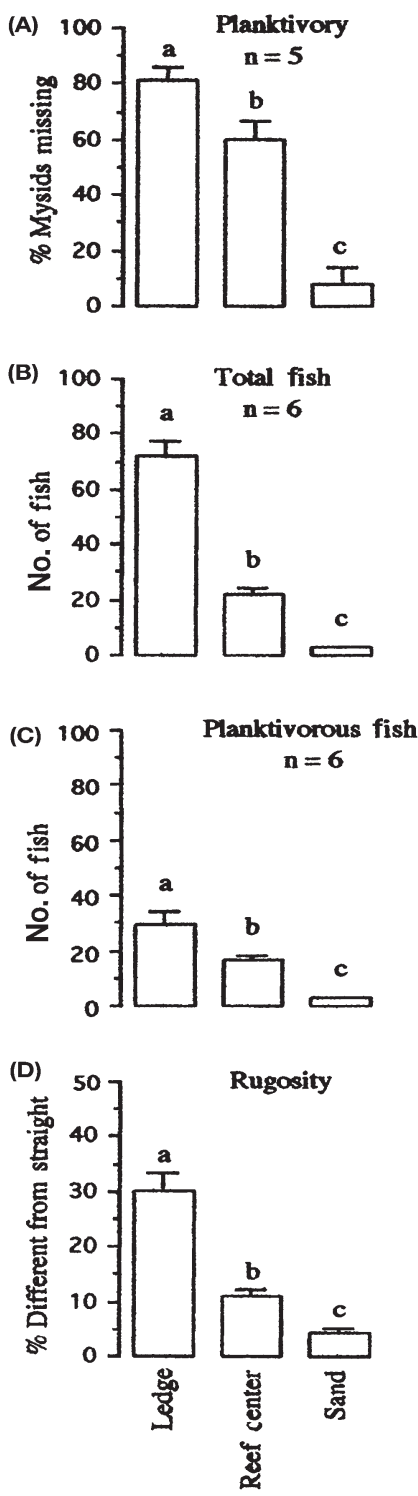

Fig. 5. Reef assays. (A) Predation risk ( $\pm 1 \mathrm{SE})$; (B) density of fishes $( \pm 1 \mathrm{SE}) ;(\mathrm{C})$ density of planktivorous fishes $( \pm 1 \mathrm{SE}) ;$ and (D) rugosity $( \pm 1 \mathrm{SE})$ for the 3 reef habitats. Letters indicate significant differences among habitats. ANOVA with TukeyKramer post-hoc analyses for predation risk and fish abundances, and Kruskal-Wallis with nonparametric Tukey-type multiple comparisons for rugosity 
Table 3. Mean density of fishes ( $\pm 1 \mathrm{SE}$ ) among our 3 reef habitats near Key Largo, Florida. ${ }^{*}$ Planktivorous species. $\mathrm{n}=6$ transects in each habitat

\begin{tabular}{|c|c|c|c|c|}
\hline \multirow{2}{*}{ Common name } & \multirow{2}{*}{ Scientific name } & \multicolumn{3}{|c|}{ - Mean no. $15 \mathrm{~m}^{-2}$} \\
\hline & & Edge & Reef center & Sand plain \\
\hline Hamlet* & Hypoplectrus unicolor & $0.2( \pm 0.2)$ & - & - \\
\hline Graysby & Epinephelus cruentatus & $0.3( \pm 0.2)$ & - & - \\
\hline Yellowtail snapper & Ocyurus chrysurus & $1.2( \pm 1.2)$ & $0.5( \pm 0.5)$ & - \\
\hline French grunt & Haemulon flavolineatum & $30.8( \pm 2.2)$ & - & - \\
\hline Smallmouth grunt & Haemulon chrysargyreum & $1.3( \pm 0.6)$ & - & - \\
\hline White grunt & Haemulon plumieri & $0.5( \pm 0.2)$ & $0.3( \pm 0.2)$ & - \\
\hline Bluestriped grunt & Haemulon sciurus & $0.5( \pm 0.2)$ & - & - \\
\hline Caesar grunt & Haemulon carbonarium & $0.2( \pm 0.2)$ & - & - \\
\hline Dusky damselfish* & Stegastes fuscus & $1.8( \pm 0.4)$ & - & - \\
\hline Beaugregory* & Stegastes leucostictus & - & $0.2( \pm 0.2)$ & - \\
\hline Bicolor damselfish* & Stegastes partitus & $9.5( \pm 0.8)$ & $3.7( \pm 0.4)$ & - \\
\hline Yellowtail damselfish & Microspathodon chrysurus & $2.5( \pm 0.6)$ & $0.2( \pm 0.2)$ & - \\
\hline Sergeant major* & Abudefduf saxatilis & $1.0( \pm 0.8)$ & - & - \\
\hline Blue chromis* & Chromis cyanea & $1.7( \pm 0.2)$ & - & - \\
\hline Brown chromis* & Chromis multilineata & $2.7( \pm 0.8)$ & - & - \\
\hline Yellowhead wrasse ${ }^{*}$ & Halichoeres garnoti & $1.7( \pm 0.4)$ & $0.8( \pm 0.3)$ & - \\
\hline Bluehead wrasse* & Thalassoma bifasciatum & $8.7( \pm 3.1)$ & $9.7( \pm 1.8)$ & - \\
\hline Slippery Dick wrasse ${ }^{*}$ & Halichoeres bivittatus & - & $0.7( \pm 0.5)$ & $2.7( \pm 0.3)$ \\
\hline Clown wrasse ${ }^{*}$ & Halichoeres maculipinna & $2.3( \pm 1.3)$ & $2.2( \pm 0.8)$ & - \\
\hline Stoplight parrotfish & Sparisoma viride & $0.5( \pm 0.3)$ & - & - \\
\hline Redband parrotfish & Sparisoma aurofrenatum & $0.8( \pm 0.5)$ & $0.7( \pm 0.7)$ & - \\
\hline Redfin parrotfish & Sparisoma chrysopterum & $0.2( \pm 0.2)$ & - & - \\
\hline Juvenile parrotfish & Sparisoma spp. & $1.0( \pm 0.8)$ & $0.5( \pm 0.5)$ & - \\
\hline Bridled goby* ${ }^{*}$ & Coryphopterus glaucofraenum & - & - & $0.2( \pm 0.2)$ \\
\hline Banded butterflyfish & Chaetodon striatus & - & $0.2( \pm 0.2)$ & - \\
\hline Foureye butterflyfish & Chaetodon capistratus & $0.3( \pm 0.3)$ & - & - \\
\hline French angelfish & Pomacanthus paru & $0.2( \pm 0.2)$ & - & - \\
\hline Blue Tang & Acanthurus coeruleus & $0.7( \pm 0.4)$ & $0.7( \pm 0.5)$ & - \\
\hline Ocean surgeonfish & Acanthurus bahianus & $1.2( \pm 0.3)$ & $1.5( \pm 0.4)$ & - \\
\hline Sharpnose pufferfish ${ }^{*}$ & Canthigaster rostrata & $0.2( \pm 0.2)$ & - & - \\
\hline
\end{tabular}

with higher rugosity had greater densities of fishes and higher rates of predation. Predation risk on the ledge was 10 times greater than on the sand plain with intermediate levels of predation on the reef center. Patterns of rugosity and fish density were qualitatively similar to those of predation risk (Fig. 5). Fish densities as a function of species and habitat are shown in Table 3.

At our seagrass site, the edge of the seagrass bed had significantly higher levels of predation risk than inside the bed or the sand plain (Fig. 6). Total fish and planktivorous fish densities in seagrass habitats showed a similar pattern (Fig. 6). Fish densities as a function of species and habitat are shown in Table 4.

\section{DISCUSSION}

PTUs were easy to transport and deploy, and they effectively documented among-habitat differences in predation risk. Numerous species of plankton were easily attached to PTUs, and the survivorship of 4 of the 5 species we tethered was 94 to $100 \%$ (Table 1). Survivorship of tethered Mysidium columbiae was lower, with $61 \%$ survivorship of tethered and $85 \%$ of untethered mysids. Although survivorship of tethered mysids was not significantly different from untethered controls (Table 1), there was a trend for lower survivorship of tethered mysids which might have been significant had we used a larger sample size.

Tethering can be a useful tool, but it can also produce artifacts (Peterson \& Black 1994, Aronson \& Heck 1995). We performed several assays to assess the PTUs for biases.

To assess among-habitat patterns of predation risk, we assumed that mysids missing from PTUs had been consumed by planktivores. If mysids escaped from PTUs, or if they were pulled off PTUs by water motion, we would overestimate predation risk. In the laboratory, plankton rarely escaped from PTUs. In field observations, $98 \%$ of mysids remained attached to PTUs unless they were attacked by predators. These results suggest that consumption accounted for almost all of the mysids missing from PTUs. 
Table 4. Mean density of fishes $\left( \pm 1 \mathrm{SE}\right.$ ) among our 3 seagrass habitats near Key Largo, Florida. ${ }^{*}$ Planktivorous species. $\mathrm{n}=6$ transects in each habitat

\begin{tabular}{|c|c|c|c|c|}
\hline \multirow{2}{*}{ Common name } & \multirow{2}{*}{ Scientific name } & \multirow[b]{2}{*}{ Sand plain } & \multicolumn{2}{|c|}{ Mean no. $15 \mathrm{~m}^{-2}$} \\
\hline & & & Edge & Inside bed \\
\hline Sand perch* & Diplectrum formosum & $0.3( \pm 0.2)$ & $0.3( \pm 0.3)$ & - \\
\hline Tobacco fish* ${ }^{*}$ & Serranus tabacarius & - & $0.3( \pm 0.2)$ & - \\
\hline Chalk bass* & Serranus tortugarum & - & $0.2( \pm 0.2)$ & - \\
\hline Juvenile spotted drum* & Equetus punctatus & - & $0.3( \pm 0.3)$ & - \\
\hline Slippery Dick wrasse ${ }^{*}$ & Halichoeres bivittatus & $1.5( \pm 1.0)$ & $7.5( \pm 0.9)$ & $3.2( \pm 2.0)$ \\
\hline Blackear wrasse $^{*}$ & Halichoeres poeyi & $0.2( \pm 0.2)$ & $0.2( \pm 0.2)$ & - \\
\hline Green razorfish* & Hemipteronotus splendens & - & $0.2( \pm 0.2)$ & - \\
\hline Rosy razorfish* ${ }^{*}$ & Hemipteronotus martinicensis & $0.2( \pm 0.2)$ & $0.3( \pm 0.2)$ & - \\
\hline Bucktooth parrotfish & Sparisoma radians & - & $0.7( \pm 0.4)$ & $1.3( \pm 1.3)$ \\
\hline Juvenile parrotfish & Sparisoma spp. & - & $0.5( \pm 0.5)$ & - \\
\hline Bridled goby ${ }^{*}$ & Coryphopterus glaucofraenum & - & $0.3( \pm 0.2)$ & - \\
\hline
\end{tabular}

Gluing plankton to PTUs might make plankton less palatable to predators or more difficult or impossible for predators to consume. We would thus underestimate relative predation risk. Fishes readily removed mysids from tethers in laboratory assays and there was no difference in the palatability of untethered versus tethered mysids. In encounters between fishes and tethered mysids in the field, fishes always removed mysids from PTUs. Thus, attaching mysids to PTUs did not reduce their acceptibility to predators.

Many planktonic organisms, including Mysidium columbiae, are transparent. Transparency is believed to make it more difficult for visual predators to detect prey (McFall-Ngai 1990, Hamner 1996, Morgan \& Christy 1996, Acosta \& Butler 1999). Additionally, planktivorous fishes have been shown to preferentially attack more conspicuous prey over less conspicuous prey (Gerking 1994, p 111-135). Because cyanoacrylate dries to an opaque white, plankton glued to PTUs might be more apparent than untethered plankton. However, live mysids and copepods with and without cyanoacrylate on their carapaces were attacked in equal proportions by fishes in the lab (Fig. 2), suggesting that gluing did not make plankton more susceptible to attack. Additionally, all species of fishes observed feeding on heat-killed mysids in the field consumed tethered (glued) and untethered (nonglued) mysids at similar rates when the mysids could not behaviorally avoid consumers (Table 2).

Some plankton behaviorally evade predators, either by avoiding portions of the water column where visual predators are active (Stich \& Lampert 1981, Gliwicz 1986), or by actively evading predator attacks (Forward 1977, Hahn \& Itzkowitz 1986, O'Brien \& Ritz 1988). Untethered Mysidium columbiae often evaded consumers, while $M$. columbiae on PTUs did not. Thus, PTUs constrain behaviorally mediated escapes. This represents a significant tethering artifact for assays
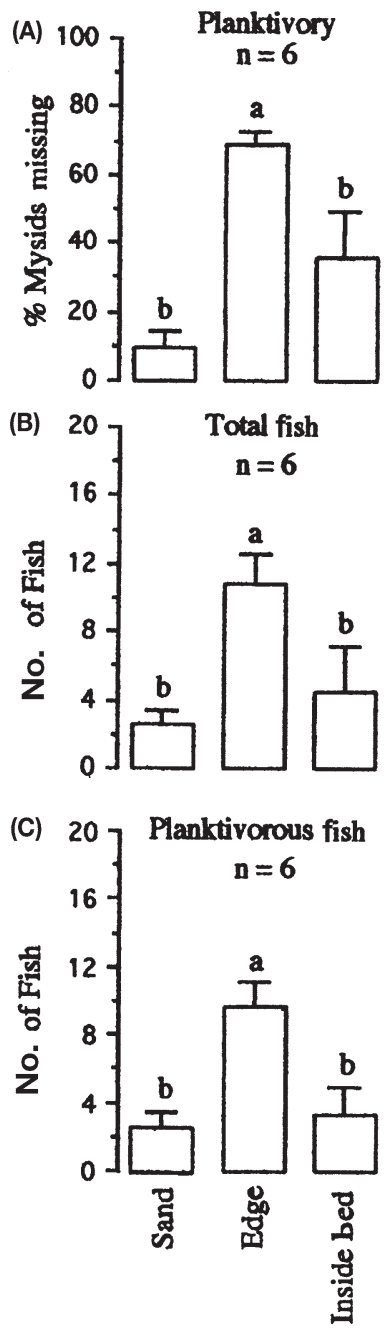

Fig. 6. Seagrass Assays. (A) Predation risk ( $\pm 1 \mathrm{SE})$; (B) density of fishes $( \pm 1 \mathrm{SE}) ;$ and $(\mathrm{C})$ density of planktivorous fishes $( \pm 1 \mathrm{SE}$ ) for the 3 seagrass habitats. ANOVA with TukeyKramer post-hoc analyses 
focused on species-specific determinations of prey susceptibility to consumers. In our field assays, however, we were interested in assessing the relative threat of predation among different habitats rather than the susceptibility of any particular species of zooplankton (e.g. mysids) to predation. Thus, this constraint was not detrimental for our particular assays. For our assays, the tethered bait had to be equally available to consumers in each habitat assayed, and the bait's behavior could not interact with habitat traits to affect attack frequency. Had mysids been able to behaviorally evade fishes while on PTUs, their behavior might have rendered them differentially susceptible to predators as a function of habitat type (e.g. they may have escaped better on topographically complex reefs than on sand plains that lacked complexity). Had such an interaction between behavior and habitat occurred, it would have been inappropriate to use mysids to assess spatial patterns of risk for plankton in general. Because we did not allow for behavioral escape or for behavior by habitat interactions, the general patterns of attack risk that we demonstrate may not translate into actual differences in consumer-induced mortality for specific zooplankton prey as they cross these habitats. Escape behaviors, chemical deterrents, and other defensive traits could cause rates of mortality to differ from rates of attack for prey species possessing these traits. However, we expect that the patterns we document would hold for zooplankton that have limited mobility and are commonly consumed by fishes, such as palatable tunicate or coral larvae (Olson \& McPherson 1987, Stoner 1990, Lindquist \& Hay 1996). Species that do not show increased mortality in high risk habitats would be obvious candidates for studies to discover the deterrent or behavioral traits diminishing their susceptibility to planktivorous fishes.

Because PTUs constrain zooplankton behavior, PTUs should not be used to assess predator generated mortality for zooplankton species that use behavioral defenses versus those that do not. In our experiments, we did not attempt to determine absolute rate of planktivory on a particular species of plankton; rather we determined the relative risk of predation in various habitats using mysids as a non-behaving bait. If PTUs made mysids more or less susceptible to different predators, this could bias our data. If this occurred, however, we would have expected differences in the relative proportions of untethered versus tethered mysids consumed by different predator species. We found no differences of this sort for any species of predator at our reef ledge and reef center sites (Table 2).

Because of the very low attack rates on the sand plain (Fig. 5), we did not compare the vulnerability of untethered versus tethered mysids to predators in this habitat. It is therefore possible that tethered mysids on the sand plain might have been unavailable to predators that would normally have consumed them; however, we see no reason to suspect this. On the ledge and reef center habitats, planktivorous fishes were abundant (Table 3) and consumed 60 to $100 \%$ of tethered mysids (Table 2, Fig. 5). In contrast, very few fishes were found on the sand plain (Fig. 5). The only fish species commonly found on the sand plain was the slippery dick wrasse Halichoeres bivittatus (Table 3). We observed $H$. bivittatus consuming mysids from PTUs on several occasions, so $H$. bivittatus was capable of detecting and removing tethered mysids if it chose to do so.

Attaching a PTU to the substratum is invasive, and could, therefore, attract or repel fishes. If either condition occurred, PTUs might not fairly measure relative levels of predation. However, in field assays, equal numbers of fishes visited sites with and without PTUs (Fig. 4), indicating that fishes were neither attracted nor repelled by PTUs.

Relative rates of predation among our reef habitats paralleled densities of planktivorous fishes, densities of total fishes, and measurements of substrate rugosity (Fig. 5). Predation risk also varied significantly among our seagrass habitats, and rates of attack in these habitats also paralleled densities of planktivorous fishes and of total fishes. In the seagrass bed, fish densities and predation risk were highest along the edge of the seagrass bed and were lower inside the bed and on the sand plain (Fig. 6). There was a 7 -fold difference in predation risk between the edge of the seagrass bed and the sand plain. Similarly, predation risk at the reef site varied by an order of magnitude between the ledge and sand plain habitats. In both of these cases, habitats with vastly different levels of predation risk occurred very close to each other. On the reef, the ledge and sand plain habitats were $25 \mathrm{~m}$ apart (separated by the reef center), while in the seagrass bed, the edge of the bed and sand plain were $3 \mathrm{~m}$ apart. Thus, the threat of predation varies dramatically over small spatial scales at these sites. Our study investigated predation risk for only a single reef and a single seagrass bed. However, if these patterns are typical for reef and seagrass beds in general, this suggests that certain habitats could serve as spatial refuges for resident zooplankton, while nearby locations would pose significant dangers. Additionally, if these patterns are general, it suggests that transient zooplankters (including marine larvae) should avoid certain areas or move through these areas quickly (selective transport) or at times of lower predation risk by visually foraging fishes (night). We note, however, that although the risk of predation for non-behaving zooplankton correlates with planktivorous fish abundance and rugosity at our reef site, zooplankton that can behaviorally evade 
predators may find more shelter, and thus experience relatively lower levels of predation, in more structurally complex habitats (Pile et al. 1996). This process would need to be evaluated on a species-specific basis.

Because planktivorous fishes feed primarily on transient zooplankters and rely upon currents to bring them a continuous supply of prey, there may be strong selection for planktivorous fishes to concentrate along the edge of habitats or on topographic highs (Bray 1981, Hobson \& Chess 1986, Hobson 1991, Kiflawi \& Genin 1997). By concentrating on these habitat borders, planktivorous fishes can gain first access to zooplankton before they become available to sessile invertebrate predators. Fish densities were significantly higher in the edge habitats of our reef and seagrass sites (Figs $5 \& 6$ ). Additionally, for our reef site, fish abundances were positively correlated with structural complexity (Fig. 5). If structural complexity equates to refuge value (Primavera 1997, Ronnback et al. 1999), areas with more complexity may provide planktivorous fishes with more shelter from their predators. The high rates of predation risk we document at our reef and seagrass edges may, therefore, result from competition between planktivores for food, the availability of refuges for planktivores, or a combination of these factors. Additional work is needed to determine whether these patterns of predation risk are typical for reefs and seagrass beds in general and to determine the underlying mechanism accounting for these differences.

Acknowledgements. Funding for this project was supported by NSF grant OCE 95-29784 to M.E.H., by an NSF pre-doctoral fellowship to S.G.B., and by the Harry and Linda Teasley endowment to the Georgia Institute of Technology. Preliminary work developing the PTU methodology was conducted at the University of North Carolina's Institute of Marine Sciences in Morehead City, North Carolina. We would like to thank N. Lindquist, A. Read, J. Grabowski, G. Cetrulo, G. Johnson, and J. Stachowicz for their help with the North Carolina portion of this project. We thank S. Lester, C. Kicklighter, A. Hollebone, R. Vidra and especially E. Sotka for their help with the Florida aspect of this project. We also thank R. Modlin for his help with mysid identification, and S. Powers for help with statistical analyses. Comments by C. H. Peterson, J. R. Pawlik, N. Lindquist, R. B. Forward Jr., and 3 anonymous reviewers improved the manuscript.

\section{LITERATURE CITED}

Acosta CA, Butler MJ IV (1999) Adaptive strategies that reduce predation on Caribbean spiny lobster postlarvae during onshore transport. Limnol Oceanogr 44:494-501

Aronson RB, Heck KL Jr (1995) Tethering experiments and hypothesis testing in ecology. Mar Ecol Prog Ser 121: 307-309

Brattegard T (1969) Marine biological investigations in the Bahamas, 10. Mysidacea from shallow water in the Bahamas and southern Florida. Part I. Sarsia 39:17-106 Bray RN (1981) Influence of water currents and zooplankton densities on daily foraging movements of blacksmith, Chromis punctipinnis, a planktivorous reef fish. Fish Bull 78:829-841

Clutter RI (1969) The microdistribution and social behavior of some pelagic mysid shrimps. J Exp Mar Biol Ecol 3: $125-155$

Davis AR, Butler AJ (1989) Direct observations of larval dispersal in the colonial ascidian Podoclavella moluccensis Sluiter: evidence for closed populations. J Exp Mar Biol Ecol 127:189-203

Emery AR (1968) Preliminary observations on coral reef plankton. Limnol Oceanogr 13:293-303

Forward RB Jr (1977) Occurrence of a shadow response among Brachyuran larvae. Mar Biol 39:331-341

Gaines SD, Roughgarden J (1987) Fish in offshore kelp forests affect recruitment to intertidal barnacle populations. Science 235:479-481

Gerking SD (1994) Feeding ecology of fish. Academic Press Inc., San Diego

Gliwicz MZ (1986) Predation and the evolution of vertical migration in zooplankton. Nature 320:746-748

Glynn PW (1973) Ecology of a Caribbean coral reef. The Porites reef-flat biotope. Part II. Plankton community with evidence for depletion. Mar Biol 22:4-21

Hahn P, Itzkowitz M (1986) Site preference and homing behavior in the mysid shrimp Mysidium gracile (Dana). Crustaceana 51:215-219

Hairston NG, Li KT, Easter SS (1982) Fish vision and the detection of planktonic prey. Science 218:1240-1242

Hamner WM (1996) Predation, cover, and convergent evolution in epipelagic oceans. In: Lenz PH, Hartline DK, Purcell JE, McMillan DL (eds) Zooplankton: sensory ecology and physiology. Gordon and Breach, Amsterdam, p 17-35

Hamner WM, Carleton JH (1979) Copepod swarms: attributes and role in coral reef ecosystems. Limnol Oceanogr 24: $1-14$

Hiatt RW, Strasburg DW (1960) Ecological relationships of the fish fauna on coral reefs of the Marshall Islands. Ecol Monogr 30:65-127

Hobson ES (1991) Trophic relationships of fishes specialized to feed on zooplankters above coral reefs. In: Sale PF (ed) The ecology of fishes on coral reefs. Academic Press, San Diego, CA, p 69-95

Hobson ES, Chess JR (1978) Trophic relationships among fishes and plankton in the lagoon at Enewetak Atoll, Marshall Islands. Fish Bull 76:133-153

Hobson ES, Chess JR (1986) Diel movements of resident and transient zooplankters above lagoon reefs at Enewetak Atoll, Marshall Islands. Pac Sci 40:7-26

Kiflawi M, Genin A (1997) Prey flux manipulation and the feeding rates of reef-dwelling planktivorous fish. Ecology 78:1062-1077

Lewis JB, Boers JJ (1991) Patchiness and composition of coralreef demersal zooplankton. J Plankton Res 13:1273-1289

Lindquist N, Hay ME (1996) Palatability and chemical defense of marine invertebrate larvae. Ecol Monogr 66: 431-450

Lindquist N, Hay ME, Fenical W (1992) Defenses of ascidians and their conspicuous larvae: adult vs. larval chemical defenses. Ecol Monogr 62:547-568

Lindquist N, Bolser R, Laing K (1997) Timing of larval release by two Caribbean demosponges. Mar Ecol Prog Ser 155: 309-313

Madhupratap MC, Achuthankutty T, Nair RS (1991) Estimates of high absolute densities and emergence rates of demersal zooplankton from the Agatti Atoll, Laccadives. Limnol Oceanogr 36:585-588 
McFall-Ngai MJ (1990) Crypsis in the pelagic environment. Amer Zool 30:175-188

Morgan SG, Christy JH (1996) Survival of marine larvae under the countervailing selective pressures of photodamage and predation. Limnol Oceanogr 41:498-504

O'Brien DP, Ritz DA (1988) Escape responses of gregarious mysids (Crustacea: Mysidacea): towards a general classification of escape response in aggregated crustaceans. J Exp Mar Biol Ecol 116:257-272

Olson RR, McPherson R (1987) Potential vs. realized larval dispersal: fish predation on the larvae of the ascidian Lissoclinum patella (Gottschaldt). J Exp Mar Biol Ecol 110: 245-256

Paffenhöffer GA, Lewis KD (1989) Feeding behavior of nauplii of the genus Eucalanus (Copepoda, Calanoida). Mar Ecol Prog Ser 57:129-136

Peterson CH, Black R (1994) An experimentalist's challenge: when artifacts of intervention interact with treatments. Mar Ecol Prog Ser 111:289-297

Pile AJ, Lipcius RN, van Montfrans J, Orth RJ (1996) Densitydependent settler-recruit-juvenile relationships in blue crabs. Ecol Monogr 66:277-300

Primavera JH (1997) Fish predation on mangrove-associated penaeids - the role of structures and substrates. J Exp Mar Biol Ecol 215:205-216

Editorial responsibility: Otto Kinne (Editor),

Oldendorf/Luhe, Germany
Ronnback P, Troell M, Kautsky W, Primavera JH (1999) Distribution patterns of shrimps and fish among Avicennia and Rizophora microhabitats in the Pagbilao mangroves Philippines Estuar Coastal Shelf Sci 48:223-234

Roughgarden J, Gaines SD, Possingham H (1988) Recruitment dynamics in complex life cycles. Science 241: $1460-1466$

Sale PF (1997) Visual census of fishes: how well do we see what is there? Proc 8th Int Coral Reef Sym 2:1435-1440

Stich HB, Lampert W (1981) Predator evasion as an explanation of diurnal vertical migration in zooplankton. Nature 293:396-398

Stoner DS (1990) Recruitment of a tropical ascidian: relative importance of pre-settlement vs. post-settlement processes. Ecology 71:1682-1690

Thetmeyer HG, Kils U (1995) To see and not be seen: the visibility of predator and prey with respect to feeding behavior. Mar Ecol Prog Ser 126:1-8

Walters K (1991) Influences of abundance, behavior, species composition, and ontogenetic stage on active emergence of meiobenthic copepods in subtropical habitats. Mar Biol 108:207-215

Walters K, Bell SS (1994) Significance of copepod emergence of benthic, pelagic, and phytal linkages in a subtidal seagrass bed. Mar Ecol Prog Ser 108:237-249

Submitted: August 10, 2000; Accepted: April 3, 2001

Proofs received from author(s): December 19, 2001 